\title{
Failure of Putative Nitrogen-fixing Bacteria to Fix Nitrogen
}

\author{
By SUSAN HILL AND J. R. POSTGA TE \\ A.R.C. Unit of Nitrogen Fixation, University of Sussex, \\ Falmer, Brighton, Sussex, BNI 9QJ
}

(Accepted for publication 27 June 1969)

\begin{abstract}
SUMMAR Y
Analyses, tests with isotopic nitrogen and tests for acetylene and isocyanide reduction, using both continuous and batch cultures, were made with seven strains of putative nitrogen-fixing bacteria and three local isolates. Only two (single strains of Mycobacterium flavum and Pseudomonas azotogensis) fixed nitrogen; the active pseudomonad differed in several respects from the organism originally reported. Other Pseudomonas, Nocardia and Azotomonas species and the three local isolates did not fix; some simulated nitrogen fixation in cultural tests most impressively, but proved simply to be very efficient scavengers of traces of fixed nitrogen.
\end{abstract}

\section{INTRODUCTION}

Over the past 15 years, several microbial species have been reported to fix nitrogen in addition to the well-known Azotobacteriaceae and the clostridia related to Clostridium pasteurianum. Nicholas (1963), L'vov (1963) and Stewart (1966) have listed or reviewed such organisms, which include species of Nocardia, Pseudomonas, Azotomonas, and Mycobacterium. Parejko \& Wilson (1968) reported complete failure to obtain nitrogen fixation by strains of Azotomonas insolita. We have examined a number of putative nitrogen-fixing bacteria obtained from culture collections and, since some strains simulated nitrogen fixation impressively in cultural studies but proved not to fix on close examination, we feel that a report of our tests is desirable.

\section{METHODS}

Organisms. The following micro-organisms were obtained from the National Collection of Industrial Bacteria (NCIB; Torry Research Station, Aberdeen, Scotland); their collection number follows their name, together with a reference to a report (if any) of their ability to fix nitrogen: Nocardia calcarea, 8863; Nocardia cellulans, 8868 (Metcalfe \& Brown, 1957); Pseudomonas azotogensis, 9277 (Paul \& Newton, I96I); Pseudomonas azotocolligans, 939I (Anderson, 1955); Azotomonas insolita, 9749 (Stapp, I940); Azotomonas fluorescens, 9884 (Krasil'nikov, 1945); Derxia gummosa, 9064 (Jensen, Petersen, De \& Bhattacharaya, I960); Azotobacter chroococcum, 8003. Professor J. De Ley kindly provided the original strain of Pseudomonas azotogensis (hereafter called 'strain V') isolated by Professor J. P. Voets (Voets \& Debacher, 1956); a culture has been deposited with the National Collection of Industrial Bacteria and assigned the number 10,386. Dr T. Kalininskaya kindly provided a culture of Mycobacterium flavum 30 I (Fedorov \& Kalininskaya, 196I). Three local 
isolates were examined, 'FINCHLEY' and 'WORCESTER' were rod-shaped facultative aerobes isolated from garden soil from North London and Worcestershire, respectively, by using Belyakov's (Belyakov, 1957) technique for Azotobacter; 'SANIBEL' was a marine aerobic rod from a sea water sample off Sanibel Island, Florida, isolated by enrichment and conventional plating on Burk sucrose medium (Newton, Wilson \& Burris, I953) supplemented with $\mathrm{NaCl} 2.5 \% \mathrm{w} / \mathrm{v}$.

Culture. Stock cultures of all aerobes except Mycobacterium flavum were maintained on Burk's sucrose agar or a comparable medium based on mannitol, though the specimens received from elsewhere had been maintained on 'nutrient agar'. Special supplements are described under the individual organisms. $M$. flavum was grown in a medium prescribed by Dr. T. Kalininskaya: $\mathrm{K}_{2} \mathrm{HPO}_{4}, \mathrm{I} \cdot 74 \mathrm{~g}$.; $\mathrm{KH}_{2} \mathrm{PO}_{4}$, 0.9I g.; $\mathrm{MgSO}_{4} \cdot 7 \mathrm{H}_{2} \mathrm{O}, 0.3 \mathrm{~g}$.; $\mathrm{CaCl}_{2} .6 \mathrm{H}_{2} \mathrm{O}$, 0.1 g.; NaCl, 0.9 g.; $\mathrm{FeCl}_{3}$, 0.0I g.; $\mathrm{NaMoO}_{4}$ $.2 \mathrm{H}_{2} \mathrm{O}, 5 \mathrm{mg}$.; biotin, $10 \mu \mathrm{g}$.; yeast extract (Difco) $80 \mathrm{mg}$.; distilled water to I l.; ethanol, $4 \mathrm{ml}$. In cases where 'adaptation' to nitrogen-fixation seemed desirable, strains were subcultured on nitrogen-deficient media at least four times before testing. Batch cultures were grown at 25 or $30^{\circ}$ in stagnant flasks, stirred flasks or stagnant standing test-tubes as appropriate; in prolonged tests the liquid level was marked and readjusted with distilled water to compensate for evaporation before sampling for nitrogen-analysis. All tests included two controls. One was a culture, in a vessel of similar dimensions to the rest, which had been boiled and acidified to about $\mathrm{N}_{-} \mathrm{H}_{2} \mathrm{SO}_{4}$; the acidification was critically important since the control thus scavenged atmospheric ammonia like an efficient nitrogen-starved ammonia-scavenging culture, which a simple boiled control would not have done. The other control was a culture of Escherichia coli (NCTC 86) as an authentic non-nitrogen fixer, incubated in conditions in which the growth was limited by the amount of ammonium salt in the medium. The $E$. coli control was also included in tests for acetylene or isocyanide reduction and incorporation of ${ }^{15} \mathrm{~N}_{2}$ (below).

Continuous cultures were set up in apparatus of the kind described by Baker (1968). When necessary, they were initiated in media containing fixed nitrogen as yeast extract or an ammonium salt and nitrogen-free medium was pumped in when the culture was established.

Nitrogen analyses. For pilot experiments, Kjeldahl digestion followed directly by Nessler analysis was used (Meynell \& Meynell, 1965). For more precise work, culture samples of 5 to $20 \mathrm{ml}$. were digested, distilled and analysed with Nessler reagent.

Isotopic nitrogen ${ }^{15} \mathrm{~N}_{2}$. Nitrogen enriched with 30 atom $\%$ of ${ }^{15} \mathrm{~N}$ was either prepared by oxidizing 30 atom \% enriched $\left(\mathrm{NH}_{4}\right)_{2} \mathrm{SO}_{4}$ with sodium hypobromite, taking care to avoid carry over of unchanged ${ }^{15} \mathrm{NH}_{3}$ (see Sprinson \& Rittenberg, 1949) or obtained by diluting 95 atom \%-enriched nitrogen gas from M.W. Hardy \& Co. (Mercantile) Ltd. (55 Basinghall St., London, E.C.2). Cultures of aerobic bacteria were grown under oxygen + argon mixtures $\mathrm{pO}_{2}=0.2$ or $0 . \mathrm{I}$ atm. with $0.2 \mathrm{~atm}$. of 30 atom $\%$ enriched $\mathrm{N}_{2}$ in closed vessels with magnetic stirring or shaking. To keep the $\mathrm{pO}_{2}$ at approximately $0 . \mathrm{I}$ atm., I $\mathrm{ml}$. gas samples were analysed for oxygen daily by gas chromatography and, when necessary, oxygen was added by injection; however, some cultures became anaerobic (see 'Results'). Burk medium was used but generally contained, in addition, the following trace elements: $\mathrm{FeSO}_{4} .7 \mathrm{H}_{2} \mathrm{O}, 0.82 \mathrm{mg}$. $\mathrm{H}_{3} \mathrm{BO}_{3}$, $2.32 \mathrm{mg}$.; $\mathrm{CoSO}_{4} .7 \mathrm{H}_{2} \mathrm{O}$, 9.56 mg.; $\mathrm{CaSO}_{4} \cdot 5 \mathrm{H}_{2} \mathrm{O}$, 0.08 mg.; $\mathrm{MnSO}_{4} \cdot \mathrm{H}_{2} \mathrm{O}, 0.08 \mathrm{mg}$.; $\mathrm{NaMoO}_{4} \cdot 2 \mathrm{H}_{2} \mathrm{O}, 0.30 \mathrm{mg}$. $\mathrm{ZnSO}_{4} \cdot 7 \mathrm{H}_{2} \mathrm{O}, \mathrm{I} \cdot 74 \mathrm{mg}$. in I l.; plus nitrilotriacetic acid, 
$56 \mathrm{mg}$./1. Sufficient fixed nitrogen was added to support visible growth but calculated to ensure nitrogen-limited conditions; the fixed nitrogen was added either as $\mathrm{NH}_{4} \mathrm{Cl}+\mathrm{I} \mu \mathrm{g}$. yeast extract $/ \mathrm{ml}$. or as yeast extract alone. After incubation each culture was digested and the ammonia distilled off. Preliminary tests showed that precautions to avoid sequential contamination due to adsorption of ${ }^{15} \mathrm{NH}_{3}$ in the still (Newman, I966) were unnecessary. The ammonia was converted to $\mathrm{N}_{2}$ with hypobromite. Gas samples were analysed in an A.E.I. M.S.3 mass spectrometer either locally or by Dr C. W. Crane (Queen Elizabeth Hospital, Birmingham). An increase of 0.015 atom $\%{ }^{15} \mathrm{~N}$ above reagent $\left(\mathrm{NH}_{4}\right)_{2} \mathrm{SO}_{4}$ or unlabelled $\mathrm{N}_{2}$ was taken as positive; in fact all positives recorded here exceeded 0.7 atom $\%{ }^{15} \mathrm{~N}$.

Isotopic nitrogen, ${ }^{13} \mathrm{~N}_{2}$. Through the courtesy of Dr N. E. R. Campbell of the University of Manitoba, Azotomonas insolita, Azotomonas fuorescens, Nocardia cellulans, Nocardia calcarea, Pseudomonas azotogensis (NCIB 9277), Pseudomonas azotogensis (strain v), Pseudomonas azotocolligans and strain 'Finchley' were tested for ${ }^{13} \mathrm{~N}_{2}$ incorporation (Campbell, Dular, Lees \& Standing, 1967). Azotobacter vinelandii was used as a positive control.

Acetylene and isocyanide reduction. All unequivocally nitrogen-fixing organisms so far examined reduce acetylene to ethylene (Dilworth, I966; Schöllhorn \& Burris, I967) and methyl isocyanide to methane (Kelly, I968). These reactions provide very sensitive tests for the presence of the nitrogenase system since the products can be detected by gas chromatography. For isocyanide reduction tests, concentrated suspensions (equiv. I to $3 \mathrm{mg}$. dry $\mathrm{wt} / \mathrm{ml}$.) in growth medium were prepared from growing cultures by centrifugation and exposed to $\mathrm{IO}^{-3} \mathrm{M}-\mathrm{CH}_{3} \mathrm{NC}$ (aqueous solution) in air in stoppered flasks up to $4 \mathrm{hr}$ at $30^{\circ}$. For acetylene reduction three types of experiments were made. (I) $10 \mathrm{ml}$. cultures were set up in $50 \mathrm{ml}$. conical flasks and, once growth had started, the cotton-wool plugs were replaced by sterile 'Suba-seal' caps, and acetylene freshly prepared from calcium carbide and water (chromatographically a purer material than commercial acetylene) was injected to about $0.02 \mathrm{~atm}$. The flasks were returned to the incubator and $0.5 \mathrm{ml}$. gas samples were removed for chromatographic analysis and replaced by $\mathrm{O}_{2}$ daily. (2) Cultures were grown on slopes of Burk's agar medium in ' universal' containers and, once growth was well established, the screw caps were replaced by 'Suba-seal' caps and acetylene injected to about $0.02 \mathrm{~atm}$. After I, 4 and $24 \mathrm{hr}$ incubation, I ml. gas samples were removed for chromatographic analysis and replaced by air. Control cultures containing no acetylene were tested in parallel. In some experiments the agar contained yeast extract $(5 \mu \mathrm{g} . / \mathrm{ml}$.). (3) Pseudomonas azotogensis NCIB 9277, Pseudomonas azotogensis strain v, Pseudomonas azotocolligans, Nocardia cellulans, Nocardia calcarea, and Azotomonas fuorescens were grown in $100 \mathrm{ml}$. batch cultures in $250 \mathrm{ml}$. flasks in Burk medium including trace elements + plus nitrilotriacetic acid $+\mathrm{NH}_{4} \mathrm{Cl},(50 \mathrm{ug} . / \mathrm{ml}$.) + yeast extract, (I $\mu \mathrm{g} . / \mathrm{ml}$.). Where necessary, chalk was present to keep the $\mathrm{pH}$ value near $7 \cdot 0$. The cultures were grown aerobically under atmospheres containing $\mathrm{pO}_{2}=0 . \mathrm{I}, \mathrm{pN}_{2}=0.2, \mathrm{pC}_{2} \mathrm{H}_{2}=$ $0.0 \mathrm{I}, \mathrm{pA}=0.69$ and anaerobically under $\mathrm{pN}_{2}=0.2, \mathrm{pC}_{2} \mathrm{H}_{2}=0.0 \mathrm{I}, \mathrm{pA}=0.79$; they were incubated on a rotary shaker and I $\mathrm{ml}$. gas samples were removed for gas-chromatographic analysis daily. The atmospheres over the aerobic cultures were renewed daily.

For tests with continuous cultures, a portion of the culture was deliberately overflowed and fresh nitrogen-free medium pumped in rapidly, so that the population ceased to be limited by any component of the medium except fixed nitrogen. Acetylene 
was then injected into the gas input line, in the non-sterile zone (before the cotton-wool filter), in amounts calculated to give about $0.02 \mathrm{~atm}$. in the growth vessel. After sufficient time had elapsed for the acetylene to be carried into the growth vessel, the gas influent and effluent lines were clipped off so as to isolate the culture vessel, with a modest positive pressure within to allow for sampling. The medium input system was also turned off. The continuous culture thus ceased to be 'continuous' but exposure of the actively growing culture to acetylene gave rapid reduction in positive cases. Samples were removed for gas analysis, using sterile syringes, either through a 'Subaseal' cap in the growth vessel or through a silicone rubber connection on the effluent line; after 2 to $5 \mathrm{hr}$ the test was stopped by opening the gas lines and restarting the flow of medium.

Gas chromatography. Acetylene and ethylene were detected on a Pye 104 gas chromatograph with a $5 \mathrm{ft}$ ( $152 \mathrm{~cm}$.) 'Porapak R' column of $4 \mathrm{~mm}$. internal diameter at $45^{\circ}$ with $\mathrm{N}_{2}$ as carrier gas at a flow rate of $60 \mathrm{ml} / \mathrm{min}$. using a flame ionization detector; ethylene production greater than $\mathrm{I} \cdot 7 \mathrm{n}$-mole $\mathrm{C}_{2} \mathrm{H}_{4} / \mathrm{ml}$. gas sample was accepted as significant provided it increased progressively with incubation. Methane from methyl isocyanide was assayed on a similar but rather less sensitive apparatus and progressive formation of $\mathrm{CH}_{4}$ in excess of $35 \mathrm{n}$-mole $/ \mathrm{ml}$. gas sample was accepted as positive. Controls without $\mathrm{C}_{2} \mathrm{H}_{2}$ or $\mathrm{CH}_{3} \mathrm{NC}$ were included in all tests. Oxygen over batch cultures was measured with a $5 \mathrm{ft}(152 \mathrm{~cm}$ ) Molecular $5 \mathrm{~A}$ sieve (I00 to I 20 mesh) column of $4 \mathrm{~mm}$. internal diameter at $40^{\circ}$ with a gas density balance (filament current $120 \mathrm{~mA}$ ) as detector. Argon was the carrier gas, at a flow rate of $25 \mathrm{ml} . / \mathrm{min}$. on the analytical side and $\mathrm{r} 20 \mathrm{ml}$./min. on the reference side.

Protein contents of bacteria. Batch cultures in Burk sucrose medium containing growth-limiting amounts of $\mathrm{NH}_{4} \mathrm{Cl}(40$ to $50 \mu \mathrm{g} . / \mathrm{ml}$.) were incubated until the organisms were well into the stationary phase. Dry weights were obtained by filtering Io to $20 \mathrm{ml}$. portions of the culture on to weighed filter membranes (Oxoid Ltd.), rinsing with distilled water, drying to constant weight at $80^{\circ}$ and reweighing; protein contents were determined by Stickland's (195I) method on centrifuged bacteria resuspended in distilled water.

\section{RESULTS}

Azotobacter chroococcum. This organism served as a positive control for our techniques. It grew readily in nitrogen-deficient media and fixed nitrogen; it was established without difficulty in continuous culture and reduced acetylene in the condition described. Suspensions reduced isocyanide readily; ${ }^{15} \mathrm{~N}_{2}$ was incorporated during growth.

Derxia gummosa. This organism is a typical awkward nitrogen fixer. On transfer to a new nitrogen-free agar or liquid medium, growth and nitrogen fixation was often delayed for 2 to 3 weeks. On agar plates, background growth would appear but good growth typical of fixation occurred only with the development of yellowish masses in isolated parts of the plates; subcultures from these zones gave a repetition of the same behaviour. This kind of behaviour was described by Jensen et al. (1960) in their original description of the organism; it made growth in nitrogen-fixing conditions in batch culture a very unreliable procedure. Various batch culture conditions were tested and reproducible growth was obtained in stagnant plugged conical flasks, with a modified Burk medium, containing $\mathrm{K}_{2} \mathrm{HPO}_{4}, 0.64$ g.; $\mathrm{KH}_{2} \mathrm{PO}_{4}$, 
0.16 g.; $\mathrm{MgSO}_{4} .7 \mathrm{H}_{2} \mathrm{O}, 0.2 \mathrm{~g}$.; $\mathrm{NaCl}, 0.2 \mathrm{~g}$.; $\mathrm{CaCl}_{2}$, I0 $\mu$ g.; mannitol, Io g;. trace elements plus nitrolitriacetic acid, as before; distilled water to I 1.; adjusted to $\mathrm{pH} 7 \cdot 9$ before autoclaving. Such flasks could be shaken if the $\mathrm{pO}_{2}$ were lowered to $\mathrm{O} \cdot \mathrm{I}$ atm. The strain was readily established in continuous culture in air by allowing it to grow in this modified Burk's medium with a little $\mathrm{NH}_{4} \mathrm{Cl}$, then running in nitrogen-deficient medium slowly. The preliminary growth with $\mathrm{NH}_{4} \mathrm{Cl}$ was unnecessary when the culture was run from the start at $\mathrm{pO}_{2}=0$. I atm. Once established it grew and fixed nitrogen continuously in air for several months provided vigorous stirring was avoided; it seemed particularly sensitive to inhibition by aeration of the kind reported by Dalton \& Postgate (1969) but, once a sufficient population was established to keep down the dissolved oxygen concentration, cultures became stable. Bacteria from the continuous culture fixed ${ }^{15} \mathrm{~N}_{2}$ in batch culture, reduced $\mathrm{CH}_{3} \mathrm{NC}$ as suspensions, and both batch cultures and the continuous culture reduced acetylene.

Mycobacterium flavum 301 . Dr Kalininskaya's medium for this organism contained about $80 \mathrm{mg}$. yeast extract/l. The organism grew to give a rather low yield in this medium but fixed nitrogen unequivocally; it doubled the nitrogen content of the medium in about to days. Batch cultures reduced acetylene about half as fast as Azotobacter chroococcum grown in a similar medium; the ability of $M$. flavum to reduce $\mathrm{CH}_{3} \mathrm{NC}$ was not tested. The organism grew without difficulty in continuous nitrogen-fixing culture; further data about this organism, including a positive test with ${ }^{15} \mathrm{~N}_{2}$, were reported by Biggins \& Postgate (I969).

Pseudomononas azotogensis, strain $\mathrm{V}$. This organism gave impressive viscid colonies on nitrogen-deficient agar and did not fix nitrogen nor reduce $\mathrm{CH}_{3} \mathrm{NC}_{\text {or }} \mathrm{C}_{2} \mathrm{H}_{2}$ under the aerobic test conditions used for Pseudomonas azotogensis NCIB 9277 and Pseudomonas azotocolligans. However, acetylene was reduced by growing cultures when initiated with a low concentration of $\mathrm{NH}_{4} \mathrm{Cl}(50 \mu \mathrm{g} . / \mathrm{ml}$. $)$ in Burk medium (containing additional trace elements, nitrilotriacetic acid (see Methods) and chalk to keep the culture neutral) if, and only if, conditions were anaerobic. Incorporation of ${ }^{15} \mathrm{~N}_{2}$ was observed: 2.57 atom $\%$ excess ${ }^{15} \mathrm{~N}$ in 12 days in a comparable medium at $\mathrm{pO}_{2}=0 \cdot \mathrm{I}$; the culture became anaerobic infrequently during the incubation period and nitrogen fixation probably occurred then. Aerobically grown suspensions of this strain appeared to incorporate ${ }^{13} \mathrm{~N}_{2}$ marginally: Dr N. E. R. Campbell recorded ${ }^{13} \mathrm{~N}$ counts $0.18 \%$ in excess of the lower limit of significance, $0.2 \%$ of the value obtained with Azotobacter vinelandii. Chalk-free batch cultures with sodium gluconate as carbon and energy source remained at about $\mathrm{pH} 7.0$ and, under anaerobic conditions, fixed $0.9 \mathrm{mg} . \mathrm{N} / \mathrm{g}$. sodium gluconate consumed. A continuous culture was established in Hino \& Wilson's medium (Hino \& Wilson, 1958) but containing no chalk and, under anaerobic conditions using nitrogen gas only, the culture fixed sufficient nitrogen (42 $\mu \mathrm{g} . / \mathrm{ml}$.) to be measured analytically. Voets \& Debacher (1956) described Pseudomonas azotogensis as a short rod, $0.5 \mu$ by 2 to $3 \mu$ and Gram-negative, actively motile with I, 3 or 4 polar flagella. The microbe was described as growing aerobically without gas and acid production on a variety of carbohydrate media. Our strain which, according to Professor De Ley, came originally from Professor Voets, was a Gramnegative rod in our hands (width $0.8 \mu$, length variable) but had peritrichous flagella. It also grew anaerobically in media containing a fixed nitrogen source, and produced acid and gas when grown in a glucose nutrient agar shake culture. A second culture sent by Professor De Ley had identical properties. These characters suggest the 
organism is not a Pseudomonas. De Ley \& Park (I966) reported that the DNA base ratio of this strain $(\mathrm{G}+\mathrm{C}=48 \cdot \mathrm{I} \%)$ was outside the normal range of Pseudomonas.

Other Pseudomonas species. Pseudomonas azotogensis NCIB 9277 and Pseudomonas azotocolligans gave impressive viscid colonies on nitrogen-deficient agar but grew only very slowly in liquid media, whether in conical flasks or upright tubes. Fixed nitrogen did accumulate in such cultures, but we attribute it to atmospheric $\mathrm{NH}_{3}$ since, even in our laboratory where ammonia is banned, control vessels accumulated 4 to $6 \mu \mathrm{g} . \mathrm{N} / \mathrm{ml}$. in 2 or 3 weeks. Methyl isocyanide was not reduced by growing cultures in a liquid medium containing limiting amounts of fixed nitrogen as $\mathrm{NH}_{4} \mathrm{Cl}$ (30 $\mu \mathrm{g} . / \mathrm{ml}$.). Acetylene was not reduced by growing cultures in any of the following conditions: on Burk medium set with agar, in liquid medium containing $80 \mu \mathrm{g}$. yeast extract $/ \mathrm{ml}$. in aerobic conditions (in which Azotobacter chroococcum and Mycobacterium flavum reduced it), in liquid medium containing $50 \mu \mathrm{g} . \mathrm{NH}_{4} \mathrm{Cl} / \mathrm{ml}$. and $\mathrm{r} \mu \mathrm{g}$. yeast extract $/ \mathrm{ml}$. in aerobic conditions but $\mathrm{pO}_{2}=0 \cdot \mathrm{I}$ atm. and the $\mathrm{pH}$ value kept near neutral. $P$. azotogensis 9277 and $P$. azotocolligans did not grow anaerobically with $\mathrm{NH}_{4} \mathrm{Cl}$ as fixed nitrogen source. Cultures of both, grown with limiting fixed nitrogen as $\mathrm{NH}_{4} \mathrm{Cl}(50 \mu \mathrm{g} . / \mathrm{ml}$. $)$ and I $\mu \mathrm{g}$. yeast extract $/ \mathrm{ml}$., incorporated no ${ }^{15} \mathrm{~N}_{2}$. $P$. azotogensis 9277 did not incorporate ${ }^{13} \mathrm{~N}_{2}$, a very small apparant incorporation was obtained with $P$. azotocolligans: Dr N. E. R. Campbell reported a ${ }^{13} \mathrm{~N}$ count $36 \%$ above the limit of significance, $3.9 \%$ of the value obtained with Azotobacter vinelandii. The organisms were readily established in continuous culture with limiting amounts of fixed nitrogen as $\mathrm{NH}_{4} \mathrm{Cl}$, but always diluted out when nitrogen-free medium was pumped in. A continuous culture of $P$. azotocolligans with limiting fixed nitrogen as yeast extract did not reduce acetylene nor fix nitrogen when grown under nitrogen with either 0.05 or $0 . \mathrm{I}$ atm. $\mathrm{O}_{2}$; sodium lactate was the carbon and energy source and $5 \% \mathrm{CO}_{2}(\mathrm{v} / \mathrm{v})$ was included in the gas phase to hold the $\mathrm{pH}$ value about $7 \cdot 0$. The culture of $P$. azotocolligans we obtained from the NCIB contained two colony types; neither bred true on subculture.

Azotomonas. Azotomonas insolita and Azotomonas fluorescens grew poorly even on solid media as compared with the pseudomonads. Similar tests to those just described for the two negative pseudomonads provided no evidence for $\mathrm{N}_{2}$ fixation, methyl isocyanide reduction or acetylene reduction; continuous cultures diluted out in nitrogen-free media. A. insolita did not incorporate ${ }^{15} \mathrm{~N}_{2}$ or ${ }^{13} \mathrm{~N}_{2}$. Two lots of $A$. fluorescens received from the NCIB appeared to contain two morphologically distinct types of colony and organisms; no attempt was made to separate them. This culture incorporated neither ${ }^{15} \mathrm{~N}_{2}$ nor ${ }^{13} \mathrm{~N}_{2}$. Experiments to test the effect of stress on these organisms and the pseudomonads are described in the next section.

Nocardia. Nocardia cellulans and Nocardia calcarea also grew poorly on solid media and were tested in parallel with the azotomonads, with similar negative results. Metcalfe \& Brown (1957) reported that these strains sometimes lost their ability to fix nitrogen in the laboratory, but that it was regained after a period of storage on sterile soil. Both strains of Nocardia, Pseudomonas azotogensis 9277 and Azotomonas insolita were stored for 2 years on sterile soil and reisolated: only $N$. cellulans and $A$. insolita survived and neither had acquired ability to fix nitrogen in our hands. Since drying on soil is a stress and might be mutagenic, three other stresses were imposed on the negative strains. Cultures of the two negative pseudomonads, azotomonads and nocardias, grown in Burk medium with added trace elements and a limiting supply 
of ammonia, were exposed separately to (I) 15 to $30 \mathrm{~min}$. at $50^{\circ}$, (2) freezing in liquid nitrogen and thawing, (3) u.v.-irradiation for 2 to $4 \mathrm{~min}$. $90 \mathrm{~mm}$. from a lamp emitting $30 \mathrm{~W}$ at $253.7 \mathrm{~m} \mu$. At least one stress caused a $50 \%$ decrease in viability, assessed by plate counts, with each strain. None developed ability to reduce acetylene after this treatment when tested on agar slopes containing $5 \mu \mathrm{g}$. yeast extract $/ \mathrm{ml}$. (see Methods).

'FINCHLEY' and 'WORCESTER'. These strains had been isolated by one of us (J. R. P.) while working in a veterinary college, and appeared from analyses to fix nitrogen if provided with small amounts $(50 \mu \mathrm{g}$. $/ \mathrm{ml}$.) of purine such as adenine or guanine. On transfer to our present address, no such fixation could be detected. Only one strain ('FINCHLEY') was tested with ${ }^{13} \mathrm{~N}_{2}$ and neither was tested in continuous culture. The importance of the site of the analyses will be brought out in the Discussion.

'SANIBEL'. This strain produced impressive growth on plates but gave no indication of nitrogen fixation in our tests.

Mixed cultures. Cultures of Azotobacter chroococcum were set up and deliberately infected with the negative aerobes to see if take-overs based on parasitism or other interactions might occur. All grew well in association, no sign of take-over by the nonAzotobacteriaceae was observed and azotobacters were the only nitrogen-fixing species we could isolate from such cultures.

\section{DISCUSSION}

The field of nitrogen fixation has a history of mysterious differences between the findings of one laboratory and another. Nevertheless, we can assert that, in our hands, there is no evidence whatever that the aerobic Pseudomonas, Azotomonas and Nocardia species, as now available from culture collections, fix nitrogen or reduce acetylene. Acetylene was not reduced even under conditions found favourable for Mycobacterium flavum. This is not to say that they did not fix nitrogen when first isolated, but either they have lost that property or they are not the original organisms. Systematic data such as their poly- $\beta$-hydroxybutyrate content (Stockdale, Ribbons \& Dawes, I968), DNA base composition (De Ley \& Park, I966) or morphology (De Ley, I968) cast doubt on their status. The one organism which did fix nitrogen consistently in our hands, Pseudomonas azotogensis strain v, provided by Professor De Ley, was already under suspicion of not being a true Pseudomonas and did not correspond to its discoverers' description. In fact it proved only to fix in anaerobic conditions, like Bacillus polymyxa or Klebsiella pneumoniae.

The question arises why some of these bacteria, particularly Pseudomonas azotogensis 9277 , give such impressive growth on nitrogen-free agar; their growth on agar resembled that of Phoma casuariniae, a non-nitrogen fixing mould, illustrated by Wilson (1952). For example, P. azotogensis 9277 on Burk agar formed, after $2 \mathrm{I}$ days at $30^{\circ}$, domed colonies 2 to $3 \mathrm{~mm}$. diam. $x$ I mm. elevation; a non-nitrogen-fixing Aerobacter aerogenes formed flat colonies I mm. diam. in similar conditions. Ammonia is present in all environments where people are working, originating as a bodily exudate; even in our laboratory where reagent ammonia solutions are banned, a plugged test tube of $\mathrm{N}-\mathrm{H}_{2} \mathrm{SO}_{4}$ can absorb nitrogen up to $6 \mu \mathrm{g}$. N/ml. in 2 to 3 weeks. An agar surface is a superior environment for scavenging atmospheric ammonia (and oxides of nitrogen for which we had no controls). If these organisms are capable of subsisting with bare minima of nitrogenous nutrients they might yield impressive growth on fixed nitrogen 
scavenged from the atmosphere. Table I shows the protein contents of nitrogen-limited cultures of various strains; since the protein contents of ordinary heterotrophs range from 50 to $70 \%$, it is clear that the protein contents of several of these strains are remarkably low. It seems likely that these organisms can form cells of unusually low nitrogen content; this view is supported by several circumstantial details. Growth of Azotomonas insolita occurred on 'nitrogen-free' media far more readily at the National

\section{Table I. Protein contents of putative nitrogen-fixing micro-organisms}

Cultures ( $100 \mathrm{ml}$.) of micro-organisms were grown with $40 \mu \mathrm{g}$. $\mathrm{NH}_{4} \mathrm{Cl} / \mathrm{ml}$. Burk medium with forced aeration and analysed for protein/dry wt micro-organism after 5 days at $30^{\circ}$. For procedures see text.

$\begin{array}{lc}\text { Organism (NCIB number) } & \text { mg. protein/mg. } \\ \text { Nocardia cellulans } \quad(8868) & 25 \\ \text { Pseudomonas azotogensis }(9277) & 36 \\ \text { Pseudomonas azotocolligans }(9391) & 12 \\ \text { Azotomonas insolita (9749) } & 10 \\ \text { Azotomonas fluorescens }(9884) & 25 \\ \text { Strain 'FINCHLEY' } & 26^{*} \\ \text { Strain 'WORCESTER' } & 28^{*}\end{array}$

* Grown in a glycerol medium, with $50 \mu \mathrm{g}$. adenine $/ \mathrm{ml}$. as fixed nitrogen, for $48 \mathrm{hr}$.

Collection of Industrial Bacteria (Aberdeen, Scotland) than at the University of Sussex; the Collection is located across an estuary from a fish market and it is thus often subject to ammoniacal components in its atmosphere. In a corroborative experiment at the National Collection, Mr A. R. MacKenzie, who used six reisolates from the original culture of $A$. insolita deposited with the Collection and two reisolates from the American Type Culture Collection's strain, showed that growth on nitrogen-deficient medium was markedly improved when ammonia-generating cultures such as Proteus spp. were in the same incubator. Finally, we should record that the original isolations of 'FINCHLEY' and 'WORCESTER' were made in a laboratory situated five floors above stables and animal houses, from which atmospheric $\mathrm{NH}_{3}$ would unquestionably arise.

These observations show how easy it is to simulate nitrogen fixation by growing aerobic microbes of exceptionally low protein content on agar in air. Such cultural tests, together with analyses, are useful preliminary tests for nitrogen fixation but they should obviously be supplemented by isotopic tests and tests for reduction of acetylene and/or other nitrogen analogues. Scavenging of traces of fixed nitrogen may account for some false positives, but it does not explain the significant enrichment of ${ }^{15} \mathrm{~N}_{2}$ obtained with Pseudomonas azotocolligans by Anderson (I955). The possibility exists that the original workers on the aerobes were handling mixed cultures of an azotobacter with a parasitic pseudomonad of the kind described by Postgate (1967) and failed to observe the azotobacter; but this is intrinsically unlikely because tests for parasitic activity among the aerobic species were negative.

\section{REFERENCES}

ANDerson, G. R. (1955). Nitrogen fixation by Pseudomonas-like soil bacteria. J. Bact. 70, I 29.

BAKER, K. (I968). Low cost continuous culture apparatus. Lab. Pract. 17, 817.

Belyakov, E. V. (1957). A new simple method for the isolation of Azotobacter from soil. Mikrobiologiya 26 (2). Quoted in RuBentchIK, L. I. (1963). Azotobacter and its Use in Agriculture. English edition, Jerusalem, Israel, Program of Scientific Translations. 
Biggins, D. R. \& Postgate, J. R. (I969). Nitrogen fixation by cultures and cell-free extracts of Mycobacterium flavum 30I. J. gen. Microbiol. 56, I8I.

Campbell, N. E. R., Dular, R., Lees, H. \& Standing, K. G. (I967). The production of ${ }^{13} \mathrm{~N}_{2}$ by 50-MeV protons for use in biological nitrogen fixation. Can. J. Microbiol. 13, 587.

Dalton, H. \& Postgate, J. R. (1969). Effect of oxygen on growth of Azotobacter chroococcum in batch and continuous culture. J. gen. Microbiol. 54, 463.

DE LEY, J. (1968). DNA base composition and classification of some more free-living nitrogen-fixing bacteria. Antonie van Leeuwenhoek 34, 66.

De LeY, J. \& PARK, I. W. (1966). Molecular biological taxonomy of some free-living nitrogen-fixing bacteria. Antonie van Leeuwenhoek 32, 6.

Dilworth, M. J. (1966). Acetylene reduction by nitrogen-fixing preparations from Cl. pasteurianum. Biochim. biophys. Acta 127, 285.

Fedorov, M. V. \& Kalininskaya, T. A. (196I). A new species of nitrogen-fixing Mycobacterium and its physiological properties. Mikrobiologiya 30, 7. (In Russian.)

Hino, S. \& WiLSON, P. W. (1958). Nitrogen fixation by a facultative Bacillus. J. Bact. 15, 403.

Jensen, H. L., Petersen, E. J., De, P. K. \& Bhattacharaya, R. (1960). A new-nitrogen-fixing bacterium: Derxia gummosa nov. gen. nov. spec. Arch. Mikrobiol. 36, 182.

KELLY, M. (1968). The kinetics of the reduction of isocyanides, acetylenes and the cyanide ion by nitrogenase preparations from Azotobacter chroococcum and the effects of inhibitors. Biochem.J. 107, I.

KrasiL'Nikov, N. A. (1945). A new species of heterotrophic nitrogen-fixer, Azotomonas fluorescens. Ref. nauchno-issled. Rab. Akad. Nauk SSSR Quoted by L'vov, N.P. (1963).

L'vov, N. P. (1963). New free-living nitrogen-fixing micro-organisms. Izv. Akad. Nauk SSSR Ser. biol. 2, 270. (in Russian).

Metcalfe, G. \& Brown, M. E. (1957). Nitrogen Fixation by a new species of Nocardia. J. gen. Microbiol. I7, 567.

Meynell, G. G. \& Meynell, E. (1965). Theory and Practice in Experimental Bacteriology, ist ed. p. 4. Cambridge: Cambridge University Press.

Newman, A. C. D. (I966). A distillation of ammonia for isotopic analysis. Chemy Ind. (3) I 5.

Newton, J. W., Wilson, P. W. \& Burris, R. H. (1953). Direct determination of ammonia as an intermediate in nitrogen fixation by Azotobacter. J. biol. Chem. 204, 445.

Nicholas, D. J. D. (1963). The biochemistry of nitrogen-fixation. Symp. Soc. gen. Microbiol. 13, 92.

Parejko, R. A. \& Wilson, P. W. (1968). Taxonomy of Azotomonas species. J. Bact. 95, 143.

PAUl, E. A. \& NewToN, J. D. (196I). Studies of aerobic non-symbiotic nitrogen-fixing bacteria. Can. J. Microbiol. 7, 7.

Postgate, J. R. (1967). Soil bacteria parasitic on Azotobacteriaceae. Antonie van Leeuwenhoek $33,113$.

SChöllhorN, R. \& Burris, R. H. (1967). Reduction of azide by the $\mathrm{N}_{2}$-fixing enzyme system. Proc. natn. Acad. Sci. U.S.A. 57, 1317.

Sprinson, D. B. \& RitTenberG, D. (1949). The rate of utilization of ammonia from protein synthesis J. biol. Chem. 180, 707 .

STAPP, C. (1940). Azotomonas insolita ein neuer aeroberstickstoffbindender Mikroorganismus. Zentbl. Bakt. ParasitKde (Abt II) 102, I.

Stewart, W. D. P. (1966). Nitrogen Fixation in Plants, ist ed. p.76 London: Athlone Press.

Stickland, L. H. (195I). The determination of small quantities of bacteria by means of the biuret reaction. J. gen. Microbiol. 5, 698.

Stockdale, H., Ribbons, D. W. \& Dawes, E. A. (1968). Occurrence of poly- $\beta$-hydroxybutrate in the Azotobacteriaceae. J. Bact. 95, 1798.

Voets, J. P. \& Debacher, J. (1956). P. azotogensis nov. spp. A new free-living nitrogen-fixing bacterium. Naturwissenschaften $43,40$.

Wilson, P. W. (I952). The comparative biochemistry of nitrogen fixation. Adv. Enzymol. 13, 345. 